\title{
Interplay between nitric oxide, ethylene, and gibberellic acid regulating the release of Amaranthus retroflexus seed dormancy
}

\author{
Jan Kępczyński ${ }^{1} \cdot$ Danuta Cembrowska-Lech $^{1} \cdot$ Paweł Sznigir $^{1}$
}

Received: 12 June 2017/Revised: 5 October 2017/ Accepted: 5 October 2017 / Published online: 22 October 2017

(C) The Author(s) 2017. This article is an open access publication

\begin{abstract}
A very small percentage, below $10 \%$, of Amaranthus retroflexus seeds were germinated at $25{ }^{\circ} \mathrm{C}$ in the light and thus the seeds were considered to be primary dormant. Nitric oxide (NO) applied for only $5 \mathrm{~h}$ stimulated germination of these non-deep physiologically dormant seeds. Likewise, ethephon, ethylene, 1-aminocyclopropane-1-carboxylic acid (ACC) and gibberellic acid $\left(\mathrm{GA}_{3}\right)$ induced dormancy release. The stimulatory effect of $\mathrm{NO}, \mathrm{ACC}$, and $\mathrm{GA}_{3}$ on germination was associated with increased ethylene production prior to radicle protrusion. The nitric oxide scavenger, cPTIO, antagonized the stimulatory effect of $\mathrm{GA}_{3}$, ethephon, and ACC on seed germination, indicating that the presence of endogenous $\mathrm{NO}$ is required for dormancy release by these compounds. This scavenger inhibited both germination and ethylene production stimulated by $\mathrm{NO}$ and $\mathrm{GA}_{3}$. An inhibitor of ethylene binding to its receptor, 2,5-norbornadiene (NBD), antagonized the beneficial effect of ethylene and NO, indicating that ethylene action is necessary for the appearance of seed response to these gases. The ACC synthase inhibitor, aminoethoxyvinylglycine (AVG), and the ACC oxidase inhibitor, $\alpha$-amino-isobutyric acid (AIB), strengthened the effect of NBD on the germination of NOpretreated seeds. Induction of germination of dormant seeds by $\mathrm{NO}$, ethephon or $\mathrm{GA}_{3}$ was associated with initiation of the cell cycle prior to radicle protrusion. The data
\end{abstract}

Communicated by A. Gniazdowska-Piekarska.

Jan Kępczyński

jankepcz@wp.pl

1 Department of Plant Physiology and Genetic Engineering, Faculty of Biology, University of Szczecin, Waska 13, 71-415 Szczecin, Poland presented indicate $\mathrm{NO}$ crosstalk with ethylene and $\mathrm{GA}_{3}$ in regulating dormancy release in A. retroflexus seeds.

Keywords Amaranthus retroflexus · Ethylene · Germination $\cdot \mathrm{GA}_{3} \cdot$ Nitric oxide $\cdot$ Primary dormancy

$\begin{array}{ll}\text { Abbreviations } \\ \text { ACC } & \text { 1-Aminocyclopropane-1-carboxylic acid } \\ \text { ACO } & \text { ACC oxidase } \\ \text { ABA } & \text { Abscisic acid } \\ \text { AIB } & \alpha \text {-Amino-isobutyric acid } \\ \text { AVG } & \text { Aminoethoxyvinylglycine } \\ \text { cPTIO } & \text { 2-(4-Carboxyphenyl)-4,4,5,5- } \\ & \text { tetramethylimidazoline-1-oxyl-3-oxide } \\ \text { ETH } & \text { Ethephon } \\ \text { GA }_{3} & \text { Gibberellic acid } \\ \text { GA } & \text { Gibberellins } \\ \text { NBD } & \text { 2,5-Norbornadiene } \\ \text { NO } & \text { Nitric oxide }\end{array}$

\section{Introduction}

Primary seed dormancy, which is common in wild plants, is induced during seed development and maturation. These seeds are not able to germinate in conditions favorable to the germination of non-dormant seeds (Bewley et al. 2013). Thus, dormancy prevents germination of intact viable seeds during temporary suitable conditions in an unfavorable season for seedling establishment. It enables the formation of weed seed banks in the soil, which can remain viable for many years. Seed dormancy, depending on the plant species, can be released during burial, stratification or dry after-ripening and/or by various chemicals (Bewley et al. 2013). Dormancy may be absolute, when seeds are unable 
to fully germinate under any environmental conditions (Rodríguez et al. 2015). However, relative dormancy also occurs in seeds; these seeds can germinate only in a narrow range of conditions compared to non-dormant seeds. Therefore, dormancy release in these seeds broadens the range of conditions suitable for germination (Bewley et al. 2013). It is commonly accepted that the balance between $\mathrm{ABA}$ and GAs and/or sensitivity to these hormones is responsible for control of the dormancy state and seed germination (Finkelstein et al. 2008; Arc et al. 2013a, b; Corbineau et al. 2014). ABA has been found to play a crucial role in the induction and maintenance of dormancy in seeds and $\mathrm{GA}_{\mathrm{s}}$ have been considered as factors involved in dormancy release and/or germination (Finkelstein et al. 2008; Rodríguez-Gacio et al. 2009). Moreover, ethylene plays a key role among hormones participating in the regulation of germination and seed dormancy (Kępczyński and Kępczyńska 1997; Matilla 2000; Matilla and MatillaVazquez 2008; Arc et al. 2013a; Corbineau et al. 2014). Ethylene stimulatory effect may occur via the involvement of $\mathrm{C}_{2} \mathrm{H}_{2}-\mathrm{GA}_{\mathrm{s}}-\mathrm{ABA}$ crosstalk (Corbineau et al. 2014). Interaction between ethylene and reactive oxygen species (ROS) in the regulation of seed germination and dormancy is also considered.

In addition to hormones, such as gibberellins and ethylene, nitrogen-containing compounds, such as nitrates, nitrites, hydroxylamines, and azides, can also break dormancy in seeds, and it was suggested that the response of seeds to nitrogenous compounds was caused by NO (Hendriks and Taylorson 1974). NO from various donors, such as nitroprusside (SNP), $S$-nitroso- $N$-acetylpenicillamine (SNAP), $S$-nitrosoglutathione (GSNO), and acidified $\mathrm{KNO}_{2}$, removes dormancy in apple, Arabidopsis, barley, lettuce, and redroot pigweed seeds (Beligni and Lamattina 2000; Bethke et al. 2004; Gniazdowska et al. 2010; Liu et al. 2011; Kępczyński and Sznigir 2014). NO produced by seeds is now recognized as a signaling molecule involved in regulating germination of dormant and non-dormant seeds in cooperation with plant hormones (Arc et al. 2013b; Krasuska et al. 2015). NO-dependent protein posttranslational modifications are proposed as a key mechanism underlying NO signaling during early seed germination (Arc et al. 2013b). Participation of plant hormones in seed dormancy release and germination involves several metabolic changes. Once dormancy has been released seeds can germinate when suitable conditions specific for the species are ensured. The germination process includes three phases distinguished on the basis of water uptake. The first two phases are regarded as germination "sensu stricto", ending in radicle protrusion. Phase I is associated with rapid water uptake, activation of respiratory metabolism, transcription, and translation. During phase II, known as the "lag phase", water content remains constant or increases slowly, and metabolic processes required for embryo growth and the completion of germination are activated. Dormant seeds are able to pass through two phases, but cannot enter phase III, which is associated with further uptake of water, major reserve mobilization, and seedling establishment. Metabolic activity in phase II of dormant seeds is lower than in nondormant seeds (Bewley et al. 2013). Data obtained for maize, Arabidopsis, and barley have shown that radicle protrusion occurring by cell elongation or cell cycle induction precedes radicle growth (Baíza et al. 1989; Masubelele et al. 2005; Gendreau et al. 2008, 2012).

The seeds of Amaranthus retroflexus, a common annual weed of 60 crops in many parts of the world (Holm et al. 1997), including Poland, are dormant after harvest and can remain viable in the soil for at least 6-10 years (Costea et al. 2004). A. retroflexus seeds express relative dormancy and therefore germinate completely after harvest at relatively high temperatures, usually $35-40{ }^{\circ} \mathrm{C}$ (Kępczyński et al. 1996; Liu et al. 2011), but do not germinate at lower temperatures until their dormancy is interrupted. There are A. retroflexus seeds which are unable to germinate after harvest or germinated only partially at $35{ }^{\circ} \mathrm{C}$ (Schönbeck and Egley 1980; Kępczyński and Sznigir 2014), indicating that the level of dormancy depends on the harvest. A. retroflexus seed dormancy can be removed by dry storage, the effect which depends on the duration and temperature of storage (Schönbeck and Egley 1980; Kępczyński and Sznigir 2014). Dormancy in these seeds also disappears as a result of burial in late autumn-winter (Egley 1989; Kępczyński and Sznigir 2013). Likewise, cold stratification has been found to remove dormancy in A. retroflexus seeds (Kępczyński and Sznigir 2013). As in the case of other seeds, A. retroflexus seed dormancy can be controlled by exogenous hormones. Ethephon, compound releasing ethylene in plant tissue, ethylene, and the ethylene biosynthesis precursor, ACC, remove dormancy, and the seeds were able to germinate at a wider range of temperatures than dormant ones (Kępczyński et al. 1996, 2003a). Likewise, $\mathrm{GA}_{3}$ was effective in removing A. retroflexus seed dormancy. The response of these seeds to $\mathrm{GA}_{3}$ and ethylene increased progressively with the duration of dry storage and stratification. Both $\mathrm{GA}_{3}$ and ethylene can partially substitute for autumn-winter burial (Kępczyński and Sznigir 2013). In contrast to $\mathrm{GA}_{3}$ and ethylene, the response to ABA decreased as the duration of stratification and burial increased by up to 3-6 months depending on the harvest (Kępczyński and Sznigir 2013). The effect of $\mathrm{GA}_{3}$ on germination of dormant A. retroflexus seeds involves ethylene biosynthesis and action (Kępczyński et al. 2003a). Seed dormancy in this species has also been partially removed by gases released from SNP, $\mathrm{NO}+\mathrm{HCN}$, and from $\mathrm{Fe}(\mathrm{II}) \mathrm{CN}, \mathrm{HCN}$ (Liu et al. 2011; 
Kępczyński and Sznigir 2014). The importance of ABA crosstalk with ethylene and nitric oxide in seed dormancy and germination was discussed in detail by Arc et al. (2013a).

There are no available data on the effect of NO on germination of physiologically non-deep dormant seeds in relation to endogenous ethylene. Information on NO interaction with gibberellin in the regulation of seed dormancy release is still inadequate. There is scant information on the role of cell cycle in relation to germination of dormant seeds. However, it was found only that dormancy release in the seeds of tomato (de Castro et al. 2001) and caryopses of Avena fatua (Cembrowska-Lech and Kępczyński 2016) was associated with the induction of DNA replication before radicle protrusion. Expression of barley grain dormancy at $30{ }^{\circ} \mathrm{C}$ is associated with a blocking of the nuclei in the phase $S$ (Gendreau et al. 2012). It is unknown whether the cell cycle is activated before radicle protrusion through the $A$. retroflexus seed coat. The effect of NO on cell cycle activity has yet to be examined in any dormant seeds.

Therefore, the aim of this work was to study the relationship between NO, ethylene, and gibberellins in regulating dormancy release in $A$. retroflexus seeds. To achieve this purpose, the effect of $\mathrm{NO}$, ethephon, $\mathrm{ACC}$, and $\mathrm{GA}_{3}$ in the absence or presence of the NO scavenger cPTIO on the germination of dormant $A$. retroflexus seeds was determined. Likewise, the ACC synthase inhibitor, AVG, and the ACC oxidase inhibitor, AIB, were used to determine whether ethylene biosynthesis is necessary in the response of seeds to $\mathrm{NO}$ or $\mathrm{GA}_{3}$. To explain whether the action of ethylene is required for $\mathrm{NO}$ and $\mathrm{GA}_{3}$ to exert an effect, we applied 2,5-norbornadiene (NBD), a competitive inhibitor of ethylene binding to its receptor. In addition, we estimated ethylene production by seeds treated with NO, ACC or $\mathrm{GA}_{3}$ before radicle protrusion through the seed coat. To clarify whether the cell cycle is activated before germination of dormant seeds, we determined the effect of NO, ethephon, and $\mathrm{GA}_{3}$ on nuclear DNA content in radicle tips prior to protrusion through the seed coat.

\section{Materials and methods}

\section{Plant material}

Amaranthus retroflexus L. (redroot pigweed) plants were collected in September 2006 near Lubniewice in Poland. The inflorescences were dried at room temperature and then gently shaken to remove the seeds. The air-dried seeds were stored at $-20{ }^{\circ} \mathrm{C}$ until use. Some experiments were done in 2013 and others in 2016.

\section{Seed treatments}

Treatment with $\mathrm{NO}, \mathrm{ETH}, \mathrm{ACC}, \mathrm{GA}_{3}, \mathrm{NO}+\mathrm{ACC}$, $\mathrm{GA}_{3}+\mathrm{ACC}$ and $\mathrm{CPTIO}$ alone or in combination with $\mathrm{NO}$, $\mathrm{ETH}, \mathrm{ACC}$ or $\mathrm{GA}_{3}$ (Scheme 1)

Three uncovered Petri dishes $(\varnothing 6 \mathrm{~cm})$ with seeds on filter paper moistened with distilled water or solution of various compounds and one open Petri dish $(\varnothing 6 \mathrm{~cm})$ containing water or $10^{-2} \mathrm{M} \mathrm{KNO}_{2}$ (NO donor) $\left(5 \mathrm{ml} 2 \times 10^{-2} \mathrm{M}\right.$ $\mathrm{KNO}_{2}$ acidified with $5 \mathrm{ml} 2 \times 10^{-1} \mathrm{M} \mathrm{HCl}$ ) were enclosed in a $19-\mathrm{cm}$ (0.5 1) Petri dish, which was sealed with Parafilm. After treatment for $5 \mathrm{~h}$, the Petri dish with the NO donor solution was replaced by a Petri dish with water. The concentration used compounds: ETH $\left(10^{-4} \mathrm{M}\right)$, $\operatorname{ACC}\left(10^{-3} \mathrm{M}\right), \mathrm{GA}_{3}\left(10^{-3} \mathrm{M}\right), \mathrm{GA}_{3}\left(10^{-3} \mathrm{M}\right)+\mathrm{ACC}$ $\left(10^{-3} \mathrm{M}\right)$, cPTIO $\left(10^{-4} \mathrm{M}\right)$, ETH $\left(10^{-4} \mathrm{M}\right)+\mathrm{cPTIO}$ $\left(10^{-4} \mathrm{M}\right)$ or $\mathrm{GA}_{3}\left(10^{-3} \mathrm{M}\right)+\operatorname{cPTIO}\left(10^{-4} \mathrm{M}\right)$ (results in Fig. 1).

Treatment with $\mathrm{NO}$ or $\mathrm{GA}_{3}$ applied alone or in combination with AVG or AIB (Scheme 1)

Seeds were incubated in water, in the presence of an inhibitor of ACC synthase activity (aminoethoxyvinylglycine, AVG) $\left(10^{-3} \mathrm{M}\right)$ or an inhibitor of ACC oxidase activity ( $\alpha$-amino-isobutyric acid, AIB) $\left(10^{-3} \mathrm{M}\right)$ in air enriched with NO. After incubation for $5 \mathrm{~h}$, the Petri dish with the NO donor solution was replaced by a Petri dish with water. Seeds were also incubated in air in water, $\mathrm{GA}_{3}$ $\left(10^{-3} \mathrm{M}\right), \operatorname{AVG}\left(10^{-3} \mathrm{M}\right), \mathrm{AIB}\left(10^{-3} \mathrm{M}\right), \mathrm{GA}_{3}+\mathrm{AVG}$ or $\mathrm{GA}_{3}+$ AIB solutions (results in Fig. 2).

Treatment with NO, applied alone or in combination with ethylene, 2,5-norbornadiene, AVG or AIB (Scheme 2)

Experiment 1 Seeds were incubated for $5 \mathrm{~h}$ in Petri dishes with water and air or air enriched with NO. Then, three uncovered Petri dishes with untreated or NO-pretreated seeds were placed in glass containers $(0.51)$ with air, air enriched with NBD $\left(10^{-6}, 3 \times 10^{-5}, 10^{-4} \mathrm{M}\right)$, air enriched with ethylene $\left(5 \times 10^{-7} \mathrm{M}\right)$ or air enriched with NBD $\left(10^{-4} \mathrm{M}\right)+$ ethylene $\left(5 \times 10^{-7} \mathrm{M}\right)$. Liquid NBD $(0.05-5.0 \mu \mathrm{l})$ was applied by syringe via the stopper onto filter paper placed under the lid of the container. The liquid evaporated completely and the final gas concentration ranged from $10^{-6}$ to $10^{-4} \mathrm{M}$. Each day during the 7-day incubation period the containers were opened and the seeds were transferred to Petri dishes with filter paper moistened with fresh water. The Petri dishes were placed in glass containers and NBD was again applied. In the treatment involving ethylene, a standard of ethylene was injected into the containers via stoppers to obtain the required 


Germination
$(7 \mathrm{~d})$$\longrightarrow \begin{aligned} & \mathrm{H}_{2} \mathrm{O}, \mathrm{NO}, \mathrm{ETH}, \mathrm{ACC}, \mathrm{GA}_{3}, \mathrm{NO}+\mathrm{ACC}, \mathrm{GA}_{3}+\mathrm{ACC}, \\ & \mathrm{cPTIO}, \mathrm{NO}+\mathrm{cPTIO}, \mathrm{ETH}+\mathrm{cPTIO}, \mathrm{ACC}+\mathrm{cPTIO}, \mathrm{GA}_{3}+\mathrm{cPTIO} \\ & \mathrm{AVG}, \mathrm{NO}+\mathrm{AVG}, \mathrm{GA} \mathrm{A}_{3}+\mathrm{AVG}, \mathrm{AIB}, \mathrm{NO}+\mathrm{AIB}, \mathrm{GA}_{3}+\mathrm{AIB}\end{aligned}$

\begin{tabular}{c}
$\begin{array}{c}\text { Ethylene } \\
\text { production } \\
(24 \text { or } 30 \mathrm{~h})\end{array} \longrightarrow \begin{array}{l}\mathrm{H}_{2} \mathrm{O}, \mathrm{NO}, \mathrm{ACC}, \mathrm{GA}_{3}, \mathrm{NO}+\mathrm{ACC}, \mathrm{GA}_{3}+\mathrm{ACC}, \\
\text { cPTIO, NO+cPTIO, GA }+ \text { cPTIO, AVG, NO+AVG, GA } 3+\mathrm{AVG}, \\
\mathrm{AIB}, \mathrm{NO}+\mathrm{AIB}, \mathrm{GA}_{3}+\mathrm{AIB}\end{array}$ \\
\hline
\end{tabular}

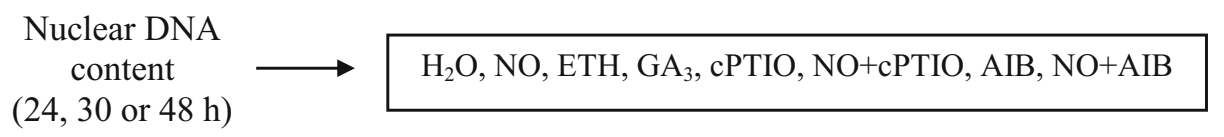

Scheme 1 The schemes of experiments with NO, ETH, ACC, GA 3 , cPTIO, AVG, and AIB

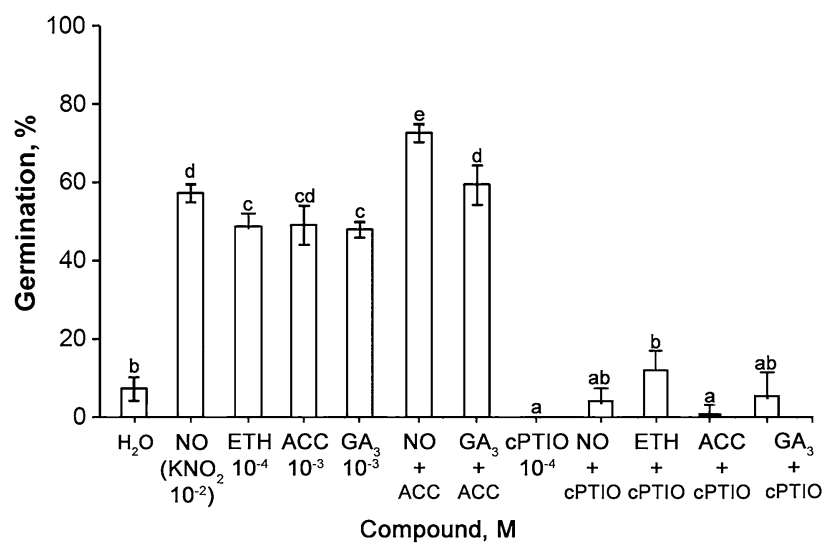

Fig. 1 The effect of $\mathrm{NO}, \mathrm{ETH}, \mathrm{ACC}, \mathrm{GA}_{3}, \mathrm{NO}+\mathrm{ACC}, \mathrm{GA}_{3}+$ ACC, cPTIO, and cPTIO in combination with NO, ETH, ACC or $\mathrm{GA}_{3}$ on germination of Amaranthus retroflexus L. seeds. The seeds were incubated in water or solution of appropriate compound(s) in air or for first $5 \mathrm{~h}$ in air enriched with NO before transfer to air. Vertical bars indicate \pm SD. One-way ANOVA with the Duncan's post hoc test on $\arcsin (x / 10)$ transformed data was used to determine the significance of differences. Mean values with different letters (a-e) are significantly different $(P<0.05)$

concentration. The ethylene concentration in the containers was tested with a gas chromatograph (results in Figs. 3, 4).

Experiment 2 Seeds were incubated for $5 \mathrm{~h}$ in Petri dishes with water and air or in water and air enriched with $\mathrm{NO}$ or $\mathrm{NO}+\mathrm{NBD}\left(10^{-4} \mathrm{M}\right)$. After $5 \mathrm{~h}$, the seeds were transferred to Petri dishes containing filter paper with fresh water. Then Petri dishes with untreated seeds or seed pretreated with $\mathrm{NO}$ or $\mathrm{NO}+\mathrm{NBD}$ were placed in glass containers $(0.51)$ with air or air enriched with ethylene $\left(5 \times 10^{-7} \mathrm{M}\right)$ (results in Table 2).

Experiment 3 Seeds were incubated for $5 \mathrm{~h}$ in Petri dishes with water and air enriched with NO. Then Petri dishes with NO-pretreated seeds were placed for $24 \mathrm{~h}$ in glass

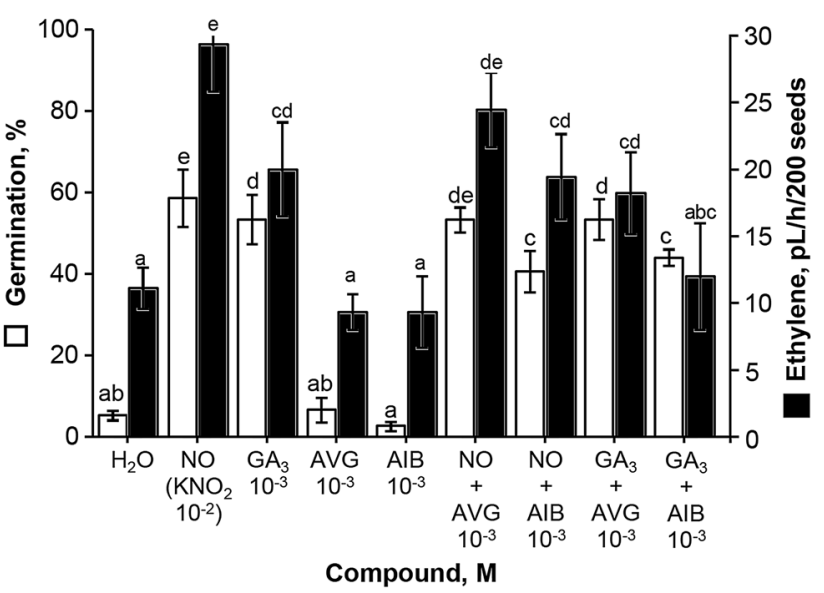

Fig. 2 The effect of $\mathrm{NO}$ or $\mathrm{GA}_{3}$ in the absence or presence of AVG or AIB on germination and ethylene production by A. retroflexus $\mathrm{L}$. seeds after incubation for $30 \mathrm{~h}$. After incubation of seeds for $27 \mathrm{~h}$ in water, $\mathrm{GA}_{3}, \mathrm{AVG}, \mathrm{AIB}, \mathrm{GA}_{3}+\mathrm{AVG}$ or $\mathrm{GA}_{3}+\mathrm{AIB}$ solution in air or air enriched with $\mathrm{NO}$ for first $5 \mathrm{~h}$, seeds were transferred to glass vials with fresh water or solutions and incubated for $3 \mathrm{~h}$ before ethylene measurement. Vertical bars indicate \pm SD. One-way ANOVA with the Duncan post hoc test was used to determine significant differences. Mean values with different letters (a-e) are significantly different $(P<0.05)$

containers $(0.51)$ with air or air enriched with NBD $\left(10^{-4}\right.$ $M)$. Seeds pretreated with NO or NO + NBD were transferred to Petri dishes with filter paper moistened with fresh water, AVG $\left(10^{-3} \mathrm{M}\right)$ or AIB $\left(10^{-3} \mathrm{M}\right)$ solution and were incubated in air (results in Table 3).

\section{Measurement of seed germination}

In all experiments, primary dormant untreated or treated seeds (50 in three replicates) were incubated at $25{ }^{\circ} \mathrm{C}$ in the light (light intensity $120 \mu \mathrm{mol} \mathrm{m} \mathrm{m}^{-2} \mathrm{~s}^{-1} ; 16 / 8 \mathrm{~h}$ photoperiod), in Petri dishes ( $\varnothing 6 \mathrm{~cm}$ ) with one layer of filter paper (Whatman no. 1) moistened with $1.5 \mathrm{ml}$ of distilled water or a solution. Seed germination was determined after 
Scheme 2 The scheme of experiments with $\mathrm{NO}$, ethylene, NBD, AVG, and AIB

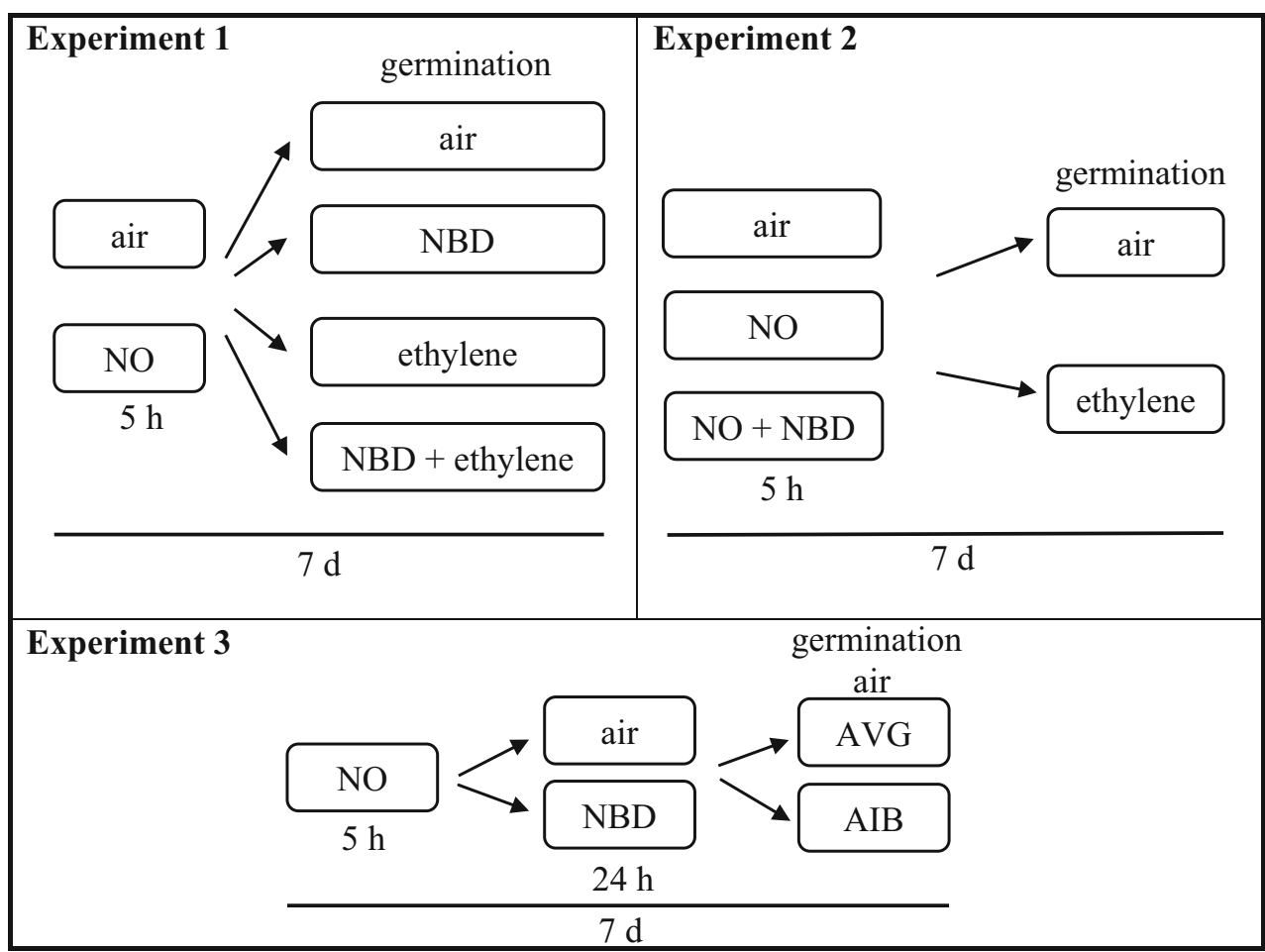

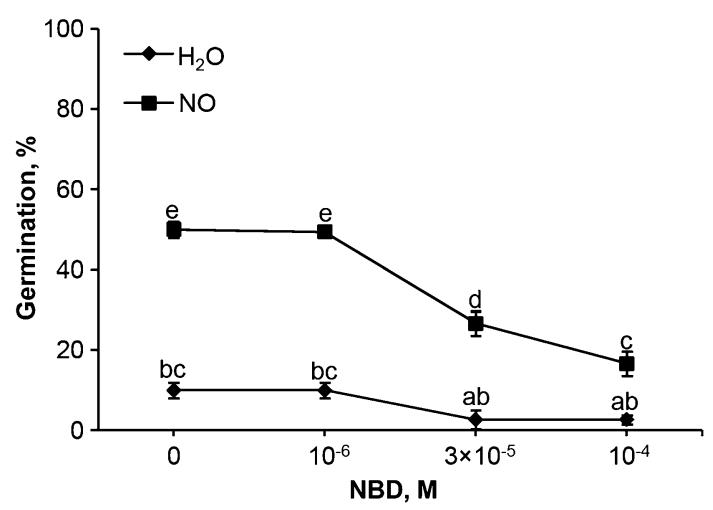

Fig. 3 The effect of NBD on germination of untreated and NOpretreated A. retroflexus L. seeds. The seeds were incubated for the first $5 \mathrm{~h}$ in water and air or in air enriched with NO before transfer to air or air enriched with NBD. Vertical bars indicate \pm SD. Two-way ANOVA with the Duncan post hoc test was used to determine significant differences. Mean values with different letters (a-e) are significantly different $(P<0.05)$

7 days of incubation. Seeds were regarded as germinated when the radicle protruded through the coat was about $2 \mathrm{~mm}$ in length.

\section{Measurement of ethylene production (Scheme 1)}

Seeds (200 in three replicates) were incubated in Petri dishes $(\varnothing 6 \mathrm{~cm})$ for 21 or $27 \mathrm{~h}$ in the light at $25^{\circ} \mathrm{C}$ in air and water or a solution of $\mathrm{GA}_{3}\left(10^{-3} \mathrm{M}\right), \mathrm{ACC}\left(10^{-3} \mathrm{M}\right)$, AVG $\left(10^{-3} \mathrm{M}\right), \operatorname{AIB}\left(10^{-3} \mathrm{M}\right), \operatorname{cPTIO}\left(10^{-4} \mathrm{M}\right)$,

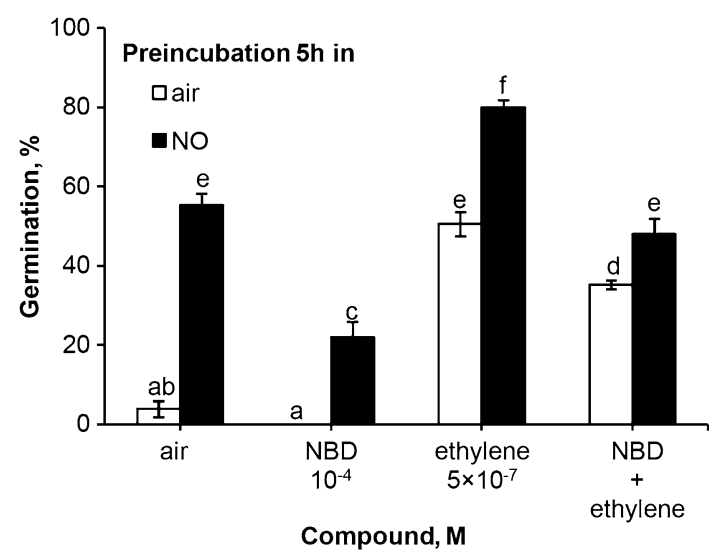

Fig. 4 The effect of NBD and ethylene on germination of untreated or NO-pretreated A. retroflexus L. seeds. The seeds were incubated for $5 \mathrm{~h}$ in water and air or air enriched with $\mathrm{NO}$ before transfer to air, NBD, ethylene or NBD + ethylene. Vertical bars indicate \pm SD. Two-way ANOVA with the Duncan post hoc test was used to determine significant differences. Mean values with different letters (a-f) are significantly different $(P<0.05)$

$\mathrm{GA}_{3}+\mathrm{AVG}, \mathrm{GA}_{3}+\mathrm{AIB}, \mathrm{GA}_{3}+\mathrm{cPTIO}$, or $\mathrm{GA}_{3}+$ ACC. Seeds were also incubated in water or solutions of ACC, cPTIO, AVG or AIB for the first $5 \mathrm{~h}$ in air enriched with NO before transfer to air up to 24 or $27 \mathrm{~h}$. Following these treatments, the seeds were transferred to 4-ml glass vials containing filter paper moistened with $0.2 \mathrm{ml}$ of fresh water or solution. The vials were sealed with rubber stoppers. After incubation for $3 \mathrm{~h}$ in the same conditions as before, gas samples of $1 \mathrm{ml}$ were taken with a syringe and 
injected into a Hewlett-Packard 5980 gas chromatograph equipped with an FID and a stainless steel column with Poropack Q 80/100 mesh. No seeds with seed coat pierced by radicle were observed in the glass vials after ethylene determination (results in Fig. 2, Table 1).

\section{Determination of nuclear DNA (Scheme 1)}

Nuclear DNA content in the radicle was determined using flow cytometry. To determine cell cycle activity, 50 seeds in three replicates were incubated in Petri dishes $(\varnothing 6 \mathrm{~cm})$ at $25{ }^{\circ} \mathrm{C}$ for $0,24,30$ or $48 \mathrm{~h}$ in the light in distilled water, cPTIO $\left(10^{-4} \mathrm{M}\right)$ or AIB $\left(10^{-3} \mathrm{M}\right)$ and air. Seeds pretreated with NO during $5 \mathrm{~h}$ of incubation in water, solutions of cPTIO $\left(10^{-4} \mathrm{M}\right)$ or AIB $\left(10^{-3} \mathrm{M}\right)$ were transferred to Petri dishes containing one layer of filter paper moistened with fresh water or solutions and incubated in air for 24 or $30 \mathrm{~h}$. In the case of treatment with ETH $\left(10^{-4} \mathrm{M}\right)$, seeds were incubated for 24 and $48 \mathrm{~h}$, and with $\mathrm{GA}_{3}\left(10^{-3}\right.$ M) for $30 \mathrm{~h}$. Fifty radicles were isolated from the imbibed seeds. Tips of radicles (approx $1 \mathrm{~mm}$ ) were chopped using a razor blade and placed in $2 \mathrm{ml}$ of a nuclei isolation buffer (45 mM $\mathrm{MgCl}_{2}, 30 \mathrm{mM}$ sodium citrate, $20 \mathrm{mM}$ MOPS, $0.1 \%$ Triton $\mathrm{X}-100$, and $2 \mu \mathrm{g} \mathrm{ml}^{-1} \mathrm{DAPI}$ ) (Galbraith et al.

Table 1 The effect of NO, ACC, GA 3 , NO + ACC, GA 3 + ACC, cPTIO and cPTIO in combination with $\mathrm{NO}$ or $\mathrm{GA}_{3}$ on ethylene production by A. retroflexus L. seeds after incubation for 24 or $30 \mathrm{~h}$

\begin{tabular}{|c|c|c|}
\hline \multirow[t]{2}{*}{ Compound, M } & \multicolumn{2}{|c|}{$\begin{array}{l}\text { Ethylene, } \mathrm{pL} / \mathrm{h} / 200 \text { seeds } \\
\text { Time, h }\end{array}$} \\
\hline & 24 & 30 \\
\hline $\mathrm{H}_{2} \mathrm{O}$ & $5.8 \pm 3.1 \mathrm{~b}$ & $7.1 \pm 2.8 b$ \\
\hline $\mathrm{NO}\left(\mathrm{KNO}_{2} 10^{-2} \mathrm{M}\right)$ & $12.4 \pm 1.5 b c$ & $32.0 \pm 4.8 \mathrm{e}$ \\
\hline ACC $10^{-3} \mathrm{M}$ & $15.4 \pm 1.9 \mathrm{bc}$ & $26.5 \pm 1.4 \mathrm{de}$ \\
\hline $\mathrm{GA}_{3} 10^{-3} \mathrm{M}$ & $14.7 \pm 1.3 \mathrm{bc}$ & $18.6 \pm 4.2 \mathrm{~cd}$ \\
\hline $\mathrm{NO}+\mathrm{ACC}$ & $23.6 \pm 4.3 \mathrm{~d}$ & $56.9 \pm 5.7 \mathrm{~g}$ \\
\hline $\mathrm{GA}_{3}+\mathrm{ACC}$ & $30.7 \pm 4.8 \mathrm{de}$ & $44.0 \pm 3.7 f$ \\
\hline cPTIO $10^{-4} \mathrm{M}$ & nd & $0 \pm 0 \mathrm{a}$ \\
\hline $\mathrm{NO}+\mathrm{cPTIO}$ & nd & $9.3 \pm 2.6 b c$ \\
\hline $\mathrm{GA}_{3}+\mathrm{cPTIO}$ & nd & $6.7 \pm 5.8 b$ \\
\hline
\end{tabular}

The seeds were incubated in water or in solution of appropriate compound(s) in air on for first $5 \mathrm{~h}$ in air enriched with NO before transfer to air. After incubation for 21 or $27 \mathrm{~h}$, seeds were transferred from Petri dishes to glass vials with fresh water or solutions and incubated for $3 \mathrm{~h}$ before ethylene measurement. Ethylene production was measured after 24 or $30 \mathrm{~h}$ of incubation, 7 or $1 \mathrm{~h}$ before radicle protrusion, respectively. Vertical bars indicate \pm SD. Two-way ANOVA with the Duncan post hoc test was used to determine significant differences. Mean values with different letters $(\mathrm{a}-\mathrm{g})$ are significantly different $(P<0.05)$

$n d$ not determined
1983) for $2 \mathrm{~min}$, after which they were incubated for $10 \mathrm{~min}$ at $25^{\circ} \mathrm{C}$. Subsequently, the suspension was passed through $20-\mu \mathrm{m}$ nylon mesh. The DAPI-stained nuclei were analyzed using a Partec PAII flow cytometer (Partec). Populations of 2C and 4C nuclei were measured on 10,000 nuclei (results in Table 4).

\section{Statistical analysis}

The mean \pm standard deviation (SD) of three replicates is shown. The means were also analyzed for significance using one-way or two-way analysis of variance (Statistica for Windows v. 10.0, Stat-Soft Inc., Tulsa, OK, USA). Duncan's multiple range test was used to determine the significance of differences $(P \leq 0.05)$ between germination percentage and biochemical assay results for $A$. retroflexus L. seeds.

\section{Results}

\section{Response of seeds to NO, ETH, ACC or GA $\mathrm{A}_{3}$ applied alone or with cPTIO}

Only a very small percentage (below 10\%) of A. retroflexus seeds is germinated at $25^{\circ} \mathrm{C}$ in the light (Fig. 1). NO, released from the $\mathrm{KNO}_{2}$ applied at $10^{-2} \mathrm{M}$, markedly enhanced the percentage of seed germination resulting in ca. $50 \%$ of seed germination. Ethephon and $\mathrm{GA}_{3}$ enhanced seed germination to a similar degree as in the case of NO. The ethylene biosynthesis precursor ACC also stimulated seed germination, resulting in ca $45 \%$ of seed germination. ACC slightly increased stimulatory effect of NO. Seeds were unable to germinate in the presence of the NO scavenger cPTIO. cPTIO markedly decreased the stimulatory effect of $\mathrm{NO}$, ethephon, $\mathrm{ACC}$, and $\mathrm{GA}_{3}$.

Ethylene production by dormant seeds incubated for 24 or $30 \mathrm{~h}$ was detected (Table 1). ACC and $\mathrm{GA}_{3}$ caused a similar level in ethylene production after $24 \mathrm{~h}$ as in the case of NO. ACC increased ethylene production induced by $\mathrm{NO}$ or $\mathrm{GA}_{3}$. After $30 \mathrm{~h}$, seeds pretreated with $\mathrm{NO}$ produced ethylene 4.5 times more effectively than untreated seeds. ACC, and $\mathrm{GA}_{3}$ also increased ethylene production after $30 \mathrm{~h}$ of incubation. Ethylene was not produced when seeds were incubated in the presence of cPTIO. cPTIO reduced ethylene production in seeds pretreated with NO. Likewise, application of cPTIO in combination with $\mathrm{GA}_{3}$ decreased ethylene production to a similar degree. 


\section{Seed response to $\mathrm{NO}$ or $\mathrm{GA}_{3}$ in the absence or presence of AVG or AIB}

Inhibitors of ethylene biosynthesis were used to determine whether ethylene biosynthesis is required to obtain the stimulatory effect of $\mathrm{NO}$ and $\mathrm{GA}_{3}$. AVG, an inhibitor of ACC synthase, and AIB, an inhibitor of ACC oxidase, did not affect seed germination (Fig. 2). AVG had no effect on the germination of NO-pretreated seeds, while AIB only slightly decreased the germination percentage. The presence of AVG during incubation with $\mathrm{GA}_{3}$ did not affect germination, but AIB again slightly decreased the percentage of germination induced by $\mathrm{GA}_{3}$. AVG and AIB did not affect ethylene production after $30 \mathrm{~h}$. AVG had no influence on ethylene production when seeds were pretreated with NO. Stimulation of ethylene production by $\mathrm{GA}_{3}$ also did not decrease under the influence of AVG. AIB slightly decreased ethylene production by seeds pretreated with NO. Simultaneous application of AIB and $\mathrm{GA}_{3}$ reduced ethylene production as well.

\section{Seed response to NO in combination with NBD, ethylene, AVG or AIB}

To examine whether ethylene action is necessary for NO to influence seed germination, NBD, a competitive inhibitor of ethylene binding to its receptor, was applied. NBD inhibited germination of dormant seeds (Fig. 3). As reported in the previous experiment, NO enhanced the percentage of seed germination. Germination of NO-pretreated seeds was markedly, 2.5 times, reduced by NBD applied continuously to these seeds. NO was also applied alone or simultaneously with NBD for $5 \mathrm{~h}$, after which the seeds were incubated in air or in air enriched with ethylene. Both NO and ethylene increased the germination percentage (Table 2). The stimulatory effect of NO was not

Table 2 The effect of ethylene on germination of untreated and pretreated with NO and NBD A. retroflexus L. seeds

\begin{tabular}{lcc}
\hline Treatment & \multicolumn{2}{l}{ Germination, \% } \\
\cline { 2 - 3 } & \multicolumn{2}{l}{ Ethylene, M } \\
\cline { 2 - 3 } & 0 & $5 \times 10^{-7}$ \\
\hline Air & $6.0 \pm 3.4 \mathrm{~b}$ & $52.7 \pm 5.0 \mathrm{c}$ \\
NO & $66.0 \pm 4.0 \mathrm{de}$ & $86.0 \pm 3.5 \mathrm{f}$ \\
NO + NBD & $0 \pm 0 \mathrm{a}$ & $72.7 \pm 1.2 \mathrm{e}$ \\
\hline
\end{tabular}

The seeds were incubated for $5 \mathrm{~h}$ in water and air, in water and air enriched with $\mathrm{NO}$, or in air enriched with $\mathrm{NO}+\mathrm{NBD}\left(10^{-4} \mathrm{M}\right)$. After incubation, seeds were transferred to air or air enriched with ethylene. Vertical bars indicate \pm SD. Two-way ANOVA with the Duncan post hoc test was used to determine significant differences. Mean values with different letters $(\mathrm{a}-\mathrm{f})$ are significantly different $(P<0.05)$ registered when NO was applied together with NBD. Ethylene reinforced the effect of NO and markedly counteracted the inhibition of the stimulatory effect of NO by NBD. In the following experiment, untreated or NO-pretreated seeds were then incubated in air or in air enriched with NBD, ethylene or NBD with ethylene. As in the previous experiment, NO and ethylene-stimulated germination and NBD inhibited it (Fig. 4). Ethylene increased the germination percentage in comparison with the untreated seeds and intensified the effect of NO. NBD reduced the beneficial effect of NO. Stimulatory effect of ethylene and also NO was less manifested when ethylene in combination with NBD was applied.

In the next experiment, NO-pretreated seeds were incubated for $24 \mathrm{~h}$ in air or air enriched with NBD and then incubated in air and in the presence of AVG or AIB. Application of NBD for $24 \mathrm{~h}$ antagonized the effect of the previously applied NO (Table 3). AIB decreased the effect of NO, and both inhibitors strengthened the inhibitory effect of NBD on the germination of NO-pretreated seeds; the percentage of inhibition caused by AVG and AIB in the presence of NBD reached 35-46\%, respectively.

\section{Nuclear DNA content in seeds treated with NO, ethephon, $\mathrm{GA}_{3}$, cPTIO, and AIB}

Nuclear DNA content was determined by flow cytometry in the radicle tips of seeds incubated in the presence of $\mathrm{NO}$, ethephon or $\mathrm{GA}_{3}$. Analysis of the dry seeds indicated that while the cells contained nuclei in $2 \mathrm{C}, \mathrm{S}$, and $4 \mathrm{C}$, but most were in $2 \mathrm{C}$ (Table $4 \mathrm{a}$ ). Imbibition in water for 30 or $48 \mathrm{~h}$ decreased the percentage of nuclei in $2 \mathrm{C}$. $\mathrm{NO}$ and $\mathrm{GA}_{3}$ markedly decreased the percentage of nuclei in $2 \mathrm{C}$ and increased the percentage in phase $\mathrm{S}$ and in $4 \mathrm{C}$ after $30 \mathrm{~h}$ of incubation. The percentage of nuclei was 1.6 lower in 2C and about 1.5 and 2.5 times higher in $\mathrm{S}$ and $4 \mathrm{C}$, respectively. Ethephon reduced the percentage of nuclei in $2 \mathrm{C}$ after $24 \mathrm{~h}$ by about $50 \%$ and increased the percentage of nuclei 1.9 and 4 times in phase $S$ and in $4 C$, respectively. Prolongation of incubation in the presence of ethephon decreased the percentage of nuclei in phase $\mathrm{S}$ and increased the percentage in $4 \mathrm{C}$. cPTIO and AIB did not affect the percentage of nuclei in all phases after 24 and $30 \mathrm{~h}$ of incubation and after $24 \mathrm{~h}$ when applied to seeds pretreated with NO (Table 4b). After $30 \mathrm{~h}$ of imbibition in the presence of CPTIO or AIB seeds pretreated with $\mathrm{NO}$, the number of nuclei in $2 \mathrm{C}$ was by 51 or $42 \%$, respectively, higher compared to the pretreated only with NO. However, cPTIO and AIB decreased the number of nuclei in $4 \mathrm{C}$ phases in NO-pretreated seeds by 3.4 and 2.1 , respectively. 
Table 3 The effect of AVG or AIB on germination of $A$. retroflexus $\mathrm{L}$. seeds pretreated with $\mathrm{NO}$ or $\mathrm{NO}+\mathrm{NBD}$

\begin{tabular}{llllll}
\hline Inhibitor, $\mathrm{M}$ & $\mathrm{NO} \rightarrow$ air & & $\mathrm{NO} \rightarrow \mathrm{NBD} \rightarrow$ air & \\
\cline { 2 - 3 } \cline { 5 - 6 } & Germination, $\%$ & Inhibition, $\%$ & & Germination, $\%$ & Inhibition, \% \\
\hline $0\left(\mathrm{H}_{2} \mathrm{O}\right)$ & $50.0 \pm 2.0 \mathrm{c}$ & - & $32.0 \pm 3.5 \mathrm{~b}$ & - \\
$\mathrm{AVG} 10^{-3}$ & $46.7 \pm 1.2 \mathrm{c}$ & $6.7 \pm 2.3 \mathrm{a}$ & & $20.7 \pm 1.2 \mathrm{a}$ & $35.4 \pm 3.6 \mathrm{~cd}$ \\
$\mathrm{AIB} 10^{-3}$ & $36.7 \pm 3.0 \mathrm{~b}$ & $26.7 \pm 6.1 \mathrm{bc}$ & & $17.3 \pm 3.0 \mathrm{a}$ & $45.8 \pm 9.5 \mathrm{~d}$ \\
\hline
\end{tabular}

Seeds were incubated in water and for the first $5 \mathrm{~h}$ in air enriched with $\mathrm{NO}\left(10^{-2} \mathrm{M}\right)$, then for $24 \mathrm{~h}$ in air or air enriched with NBD $\left(10^{-4} \mathrm{M}\right)$. Then they were incubated in air and water or in air and AVG or AIB solution. Vertical bars indicate \pm SD. Two-way ANOVA with the Duncan post hoc test was used to determine significant differences. Mean values with different letters (a-e) are significantly different $(P<0.05)$

\section{Discussion}

The seeds of A. retroflexus, a common and important summer annual weed all over the world, are physiologically non-deep dormant after harvest (Baskin and Baskin 2014). This dormancy, which can be considered as relative dormancy, is expressed as the inhibition of germination only at relatively low temperatures. The application of various physical or chemical factors enables them to germinate at lower temperatures thereby extending the temperature range suitable for germination. The A. retroflexus seeds used in the present experiments were dormant, and therefore germination at $25{ }^{\circ} \mathrm{C}$ in the light was very poor, not exceeding $10 \%$ (Figs. 1, 2, 3, 4). Dormancy in these seeds was removed by $\mathrm{NO}$ released from acidified $\mathrm{KNO}_{2}$. Likewise, the application of SNP, NO, and HCN donors, for 7 days (Liu et al. 2011) or for 1 day, have stimulated germination of these seeds (Kępczyński and Sznigir 2014). The results presented here showed that NO released from the $\mathrm{KNO}_{2}$ applied for only $5 \mathrm{~h}$ was sufficient to remove dormancy (Figs. 1, 2, 3, 4). Similarly, short-term treatment of dormant apple embryos with NO has been shown to stimulate their germination (Gniazdowska et al. 2007). Reducing the stimulatory effect of NO with the widely used scavenger cPTIO, which is highly specific to NO (D'Alessandro et al. 2013), confirmed that NO is responsible for dormancy release in A. retroflexus seeds. The beneficial effect of NO from various donors, usually applied for at least 1 day, on the germination of dormant and non-dormant seeds of several plant species has been described previously (Bethke et al. 2007; Arc et al. 2013a, b; Krasuska et al. 2015).

Seed dormancy of A. retroflexus can be removed by ethylene liberated from ethephon taken up by seeds (Kępczyński et al. 1996; Fig. 1). The response of A. retroflexus seeds to ethylene applied as a gas (Kępczyński et al. 2003a; Fig. 4) is evidence of the significance of this hormone in releasing dormancy. The important role of ethylene in releasing dormancy of Amaranthus seeds is supported by the very high sensitivity of both primary dormant A. retroflexus (Kępczyński et al. 1996) and secondary dormant $A$. caudatus seeds (Kępczyński et al. 2003b), as it can substantially or completely remove dormancy at very low concentrations. Stimulation of germination of A. retroflexus seeds by exogenously applied ACC, a precursor of ethylene biosynthesis which is converted to ethylene (Fig. 1, Table 1), also supports the role of ethylene in releasing dormancy. Moreover, it indicates that ACC oxidase is partially active in these dormant seeds. Induction of germination of these seeds by exogenous ACC, which is metabolized to ethylene (Table 1), as well as the lower content of endogenous ACC in dormant seeds than in non-dormant seeds (Kępczyński et al. 2003a), suggests that dormancy is associated with insufficient production of ethylene caused by too low content of endogenous ACC. The significant role of ethylene in the germination of primary and secondary dormant seeds as well as non-dormant seeds has been discussed in previously published reviews (Kępczyński and Kępczyńska 1997; Matilla 2000; Corbineau et al. 2014).

However, additional knowledge is still required, especially regarding the interaction of ethylene with other molecules. The significant role of ethylene in removing $A$. retroflexus seed dormancy also stems from the increase in its production as soon as $1 \mathrm{~h}$, before radicle protrusion through the coat of seeds treated with dormancy-releasing factors (Table 1).

The opposite effects of NO scavengers derivatives of PTIO to those of NO donors are usually considered to be reliable evidence of NO implication in physiological processes (Arc et al. 2013b). Removal of NO by application of its scavenger, cPTIO, simultaneously with ethephon or ACC prevents the stimulatory effect of these compounds (Fig. 1), indicating that NO is required for the seed response to ethylene. The fact that ethylene or ACC increases the beneficial effect of NO (Figs. 1,4) on germination indicates a positive interaction between these compounds in regulating the removal of dormancy. In addition to ethylene, $\mathrm{GA}_{3}$ was also able to induce the germination of dormant $A$. retroflexus seeds (Figs. 1, 2), 
Table 4 Effects of NO $\left(\mathrm{KNO}_{2} 10^{-2} \mathrm{M}\right)$, GA $3\left(10^{-3} \mathrm{M}\right)$, ETH $\left(10^{-4} \mathrm{M}\right)$, cPTIO $\left(10^{-4} \mathrm{M}\right)$, AIB $\left(10^{-3} \mathrm{M}\right)$, NO + cPTIO or NO + AIB on the nuclear DNA content in radicles of $A$. retroflexus $\mathrm{L}$. seeds after incubation for different periods

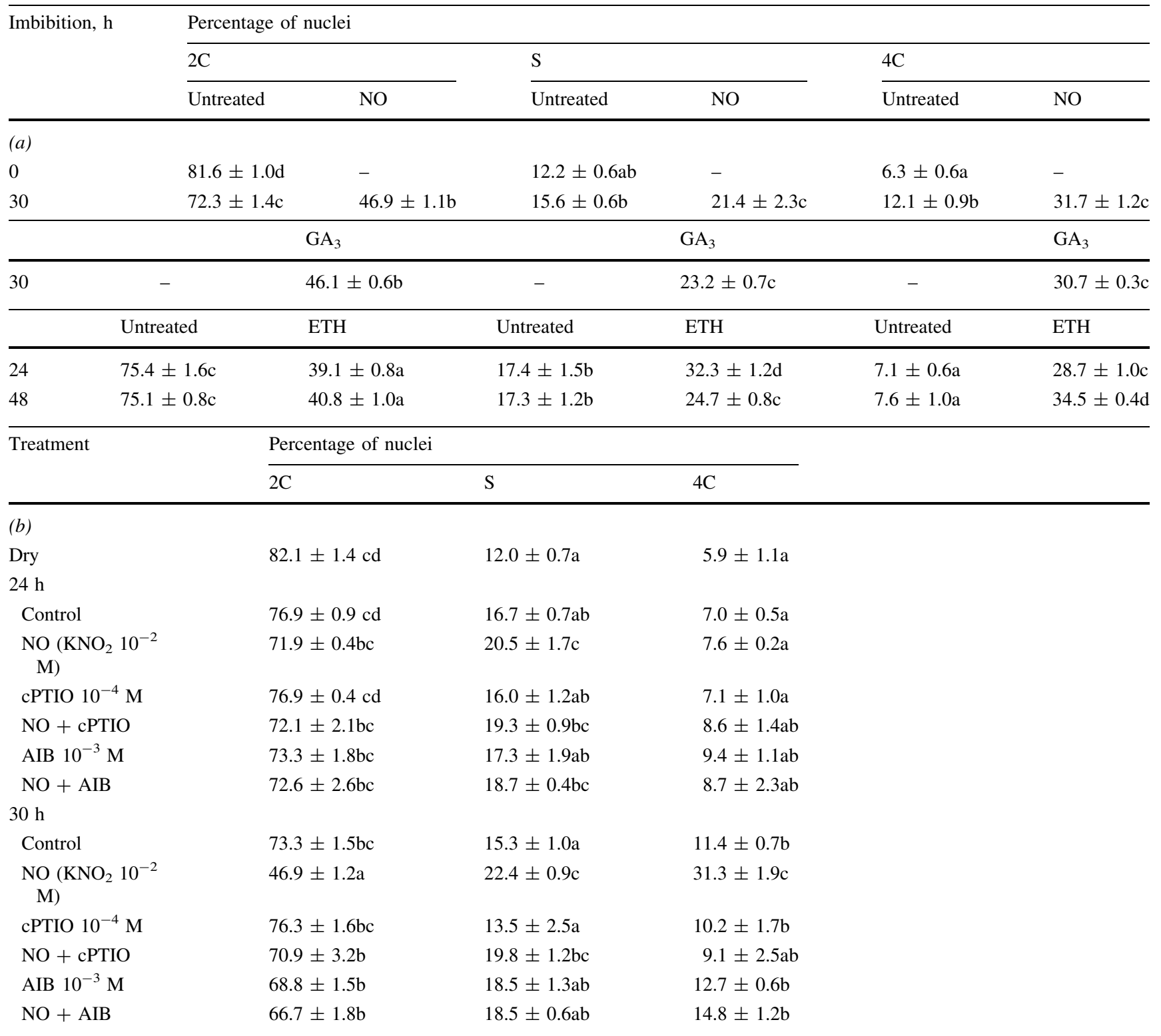

The first seeds with seed coat pierced by the radicle were observed ca $1 \mathrm{~h}$ after the determination of nuclear DNA content in seeds incubated for $24 \mathrm{~h}$ with ETH or $30 \mathrm{~h}$ with $\mathrm{NO}$ or $\mathrm{GA}_{3}$. After $48 \mathrm{~h}$ of incubation in ETH solution, about $60 \%$ of seeds were germinated. Vertical bars indicate \pm SD. Two-way ANOVA with the Duncan post hoc test was used to determine significant differences. Mean values with different letters $(\mathrm{a}-\mathrm{d})$ are significantly different $(P<0.05)$

which is in agreement with previous findings (Kępczyński et al. 1996). The impact of $\mathrm{GA}_{3}$ can also be blocked through the removal of endogenous NO by cPTIO (Fig. 1), showing that not only ethylene but also gibberellin provides evidence of the need for nitric oxide. Dormancy removal in Arabidopsis seeds by NO was associated with enhanced transcription of GA3oxl and GA3ox2 (Bethke et al. 2007). Likewise, an interaction between gibberellin and ethylene in regulating seed germination has been shown in several experiments. Inhibition of germination of non-dormant $A$. caudatus seeds by tetcyclacis, an inhibitor of gibberellin biosynthesis, was reversed by $\mathrm{GA}_{4+7}$ and also by ethephon or ACC (Kępczyński 1986a). In experiments with Arabidopsis seeds, $\mathrm{GA}_{3}$ was found to induce germination of the etrl mutant (Bleecker et al. 1988) and ethylene-stimulated germination of the GA-deficient gal mutant (Karssen et al. 1989). 
Moreover, induction by $\mathrm{GA}_{3}$ and $\mathrm{NO}$ ethylene production before radicle protrusion of A. retroflexus dormant seeds (Table 1) suggest that release dormancy in these seeds by above compounds involves control of ethylene biosynthesis. This result also indicates that dormancy release was ethylene-dependent. Moreover, cPTIO, in addition to reducing germination, also decreased ethylene production enhanced by $\mathrm{NO}$ and $\mathrm{GA}_{3}$ (Table 1), confirming that the presence of $\mathrm{NO}$ is necessary for the stimulatory effect of both compounds.

In light of these data, we can postulate NO crosstalk with ethylene and $\mathrm{GA}_{3}$ in regulating dormancy release of A. retroflexus seeds. Crosstalk between NO and ethylene in the regulation of dormancy release of apple embryos (Gniazdowska et al. 2010) and germination under salinity of non-dormant Arabidopsis seeds (Lin et al. 2013) has previously been demonstrated. The stimulatory effect of $\mathrm{NO}$ and $\mathrm{GA}_{3}$ on A. retroflexus seed germination was not affected by the ACC synthase inhibitor AVG, which also had no effect on ethylene production (Fig. 2). However, AIB, an inhibitor of ACC oxidase, slightly influenced both ethylene production and germination of seeds treated with $\mathrm{NO}$ or $\mathrm{GA}_{3}$. This may to a small degree suggest action of $\mathrm{NO}$ and $\mathrm{GA}_{3}$ via the stimulation of ethylene biosynthesis. Previous studies in which inhibitors of ethylene biosynthesis were applied to seeds have provided varied data. Significant reduction in the stimulatory effect of $\mathrm{GA}_{3}$ on $A$. retroflexus seed germination was obtained by applying $\mathrm{CoCl}_{2}$, a nonspecific inhibitor of ACC conversion to ethylene (Kępczyński et al. 2003a). An earlier study showed that AVG simultaneously inhibited the release from secondary dormancy of Amaranthus caudatus seeds by $\mathrm{GA}_{3}$ as well as ethylene production stimulated by this compound (Kępczyński et al. 2006). An inhibitor of ACS activity, $\alpha$-aminoisobutyric acid, inhibited the germination of partially dormant and non-dormant apple embryos (Kępczyński et al. 1977), and AVG inhibited germination of dormant apple embryos pretreated with NO (Gniazdowska et al. 2010). It has also been demonstrated that both AVG and $\mathrm{CoCl}_{2}$ suppress the stimulatory effect of glutamate on the germination of cucumber seeds under salt stress (Chang et al. 2010). In the case of non-dormant Amaranthus caudatus seeds, even strong reduction of ethylene production by AVG did not inhibit germination, but the seeds still produced a certain amount of ethylene, which probably was sufficient for their germination (Kępczyński and Karssen 1985). However, while AVG did not affect the germination of non-dormant $A$. caudatus seeds, it did reduce the acceleration of seed germination by $\mathrm{GA}_{4+7}$, indicating the ethylene-dependent effect of this gibberellin (Kępczyński 1986a). Moreover, AVG increased germination inhibition caused by tetcyclacis or $\mathrm{ABA}$ (Kępczyński 1986a, b).
As an alternative to using inhibitors of ethylene biosynthesis, manipulation of the availability of ethylene receptors provides very important information on the functions of ethylene alone or together with other compounds, since ethylene action is crucial for the germination of dormant and non-dormant seeds. NBD, an ethylene inhibitor binding to its receptor, counteracts the effect of ethylene on germination of non-dormant and secondary dormant A. caudatus seeds (Kępczyński and Karssen 1985; Kępczyński et al. 2006) and primary dormant A. retroflexus seeds (Kępczyński et al. 2003a; Fig. 4), indicating the necessity of ethylene action for germination of these seeds. NBD applied simultaneously with NO for $5 \mathrm{~h}$ (1), for $24 \mathrm{~h}$ to NO-pretreated seeds (2) or continuously after pretreatment with NO (3) reduced the beneficial effect of NO on the release of $A$. retroflexus seed dormancy (Table 2, 3; Figs. 3, 4), which indicates that ethylene action is required to reveal the effect of $\mathrm{NO}$, and also demonstrates the importance of ethylene in response to this compound. Blocking of ethylene receptors by NBD in NO-pretreated apple embryos also prevented the stimulating influence of nitric oxide (Gniazdowska et al. 2010). The release of dormancy in A. retroflexus seeds by $\mathrm{GA}_{3}$ (Kępczyński et al. 2003a; Fig. 3) was also strongly antagonized by NBD (Kępczyński et al. 2003a), which suggests that ethylene action is required for dormancy release by this compound. Application of AVG and AIB in combination with NBD intensified the inhibitory effect of NBD on germination of NO-pretreated seeds (Table 3), demonstrating the significance of ethylene and the need for its synthesis in response to NO.

To determine whether dormancy breaking by NO, ethylene, and $\mathrm{GA}_{3}$ involves cell cycle activation, flow cytometry was used to analyze the content of nuclear DNA in the tips of radicles isolated from seeds. As in previous experiments with tomato, barley, and A. fatua (Bino et al. 1993; Gendreau et al. 2012; Cembrowska-Lech and Kępczyński 2016), most of the cells in the radicles from dry seeds were arrested in phase $G_{1}$ of the cell cycle (Table 4). The percentage of nuclei in dry A. retroflexus seeds in phase $S$ and $G_{2}$ was much lower than the percentage in phase $\mathrm{G}_{1}$. Imbibition of dormant seeds in water for 24 or $30 \mathrm{~h}$ slightly decreased the percentage of nuclei in $G_{1}$ and doubled the percentage of $G_{2}$ nuclei after $30 \mathrm{~h}$. $\mathrm{NO}$ and $\mathrm{GA}_{3}$, stimulating germination of A. retroflexus dormant seeds, decreased the percentage of nuclei in $\mathrm{G}_{1}$ and increased in the percentage in $\mathrm{S}$, and more so in $\mathrm{G}_{2}, 1 \mathrm{~h}$ before radicle protrusion (Table 4a). Ethylene also decreased the percentage of nuclei in $\mathrm{G}_{1}$ and increased the percentage in $S$ and $G_{2} 1 \mathrm{~h}$ before radicle protrusion (after $24 \mathrm{~h}$ of incubation). The inhibition of seed germination of NO-pretreated seeds by cPTIO and AIB, was associated with lowering number of nuclei in phase G2 (Table $4 b$ ). 


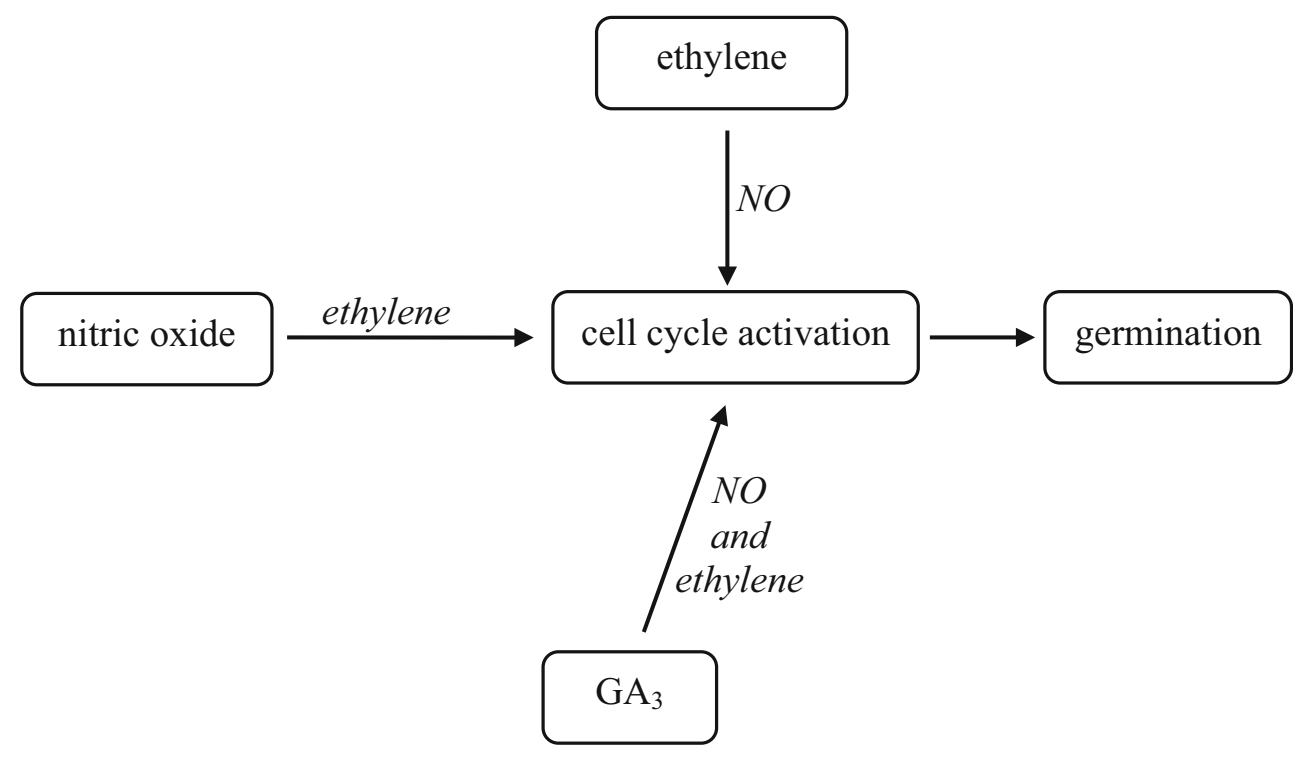

Scheme 3 The model of interaction between NO, ethylene, and $\mathrm{GA}_{3}$ in germination induction of dormant A. retroflexus $\mathrm{L}$. seeds

Above data may indicate that induction of dormancy release and germination of seeds by these compounds involves initiation of the cell cycle prior to radical protrusion. Previously, A. fatua seed dormancy release by smoke water, $\mathrm{KAR}_{1}$, and $\mathrm{GA}_{3}$ was found to initiate the cell cycle before germination (Cembrowska-Lech and Kępczyński 2016, 2017).

The results presented here show the essential role of ethylene in releasing dormancy in $A$. retroflexus seeds (Scheme 3). Nitric oxide applied for only $5 \mathrm{~h}$ was able to release dormancy to a similar degree as did ethylene or $\mathrm{GA}_{3}$. The germination of dormant seeds due to $\mathrm{NO}$ or $\mathrm{GA}_{3}$ treatment was preceded by an increase in the production of ethylene, indicating that the dormancy-releasing effect of both compounds is ethylene-dependent. The response of seeds to NO, as shown earlier for $\mathrm{GA}_{3}$ (Kępczyński et al. 2003a), required ethylene action. On the other hand, induction of germination of dormant seeds by NO, ethylene or $\mathrm{GA}_{3}$ required the presence of NO. Dormancy release and germination caused by NO, ethylene, and $\mathrm{GA}_{3}$ was associated with activation of the cell cycle prior to radicle protrusion.

Author contribution statement JK initiated and designed the research, interpreted the results, wrote the manuscript and provided the funding. DC-L conducted most experiments and statistical analysis. PS conducted some experiments.

\section{Compliance with ethical standards}

Conflict of interest The authors declare that they have no conflict of interest.
Open Access This article is distributed under the terms of the Creative Commons Attribution 4.0 International License (http://crea tivecommons.org/licenses/by/4.0/), which permits unrestricted use, distribution, and reproduction in any medium, provided you give appropriate credit to the original author(s) and the source, provide a link to the Creative Commons license, and indicate if changes were made.

\section{References}

Arc E, Sechet J, Corbineau F, Rajjou L, Marion-Poll A (2013a) ABA crosstalk with ethylene and nitric oxide in seed dormancy and germination. Front Plant Sci 4:63. doi:10.3389/fpls.2013.00063

Arc E, Galland M, Godin B, Cueff G, Rajjou L (2013b) Nitric oxide implication in the control of seed dormancy and germination. Front Plant Sci 4:346. doi:10.3389/fpls.2013.00346

Baíza AM, Vázquez-Ramos J, Sánchez de Jiménez E (1989) DNA synthesis and cell division in embryonic maize tissues during germination. J Plant Physiol 135:416-421. doi:10.1016/S01761617(89)80097-5

Baskin CC, Baskin JM (2014) Seeds: ecology, biogeography, and evolution of dormancy and germination, 2nd edn. Academic Press, New York

Beligni MV, Lamattina L (2000) Nitric oxide stimulates seed germination and de-etiolation, and inhibits hypocotyl elongation, three light-inducible responses in plants. Planta 210:215-221. doi: 10.1007/PL00008128

Bethke PC, Gubler F, Jacobsen JV, Jones R (2004) Dormancy of Arabidopsis seeds and barley grains can be broken by nitric oxide. Planta 219:847-855. doi:10.1007/s00425-004-1282-x

Bethke PC, Libourel IGL, Aoyama N, Chung YY, Still DW, Jones RL (2007) The Arabidopsis aleurone layer responds to nitric oxide, gibberellin, and abscisic acid and is sufficient and necessary for seed dormancy. Plant Physiol 143:1173-1188. doi:10.1104/pp. 106.093435

Bewley JD, Bradford KJ, Hilhorst HWM, Nonogaki H (2013) Seeds: physiology of development, germination and dormancy, 3rd edn. Springer, New York 
Bino RJ, Lanteri S, Verhoeven HA, Kraak HL (1993) Flow cytometric determination of nuclear replication stage in seed tissues. Ann Bot 72:181-187. doi:10.1006/anbo.1993.1097

Bleecker AB, Estelle MA, Somerville C, Kende H (1988) Insensitivity to ethylene conferred by a dominant mutation in Arabidopsis thaliana. Science 241:1086-1089. doi:10.1126/ science.241.4869.1086

Cembrowska-Lech D, Kępczyński J (2016) Gibberellin-like effects of $\mathrm{KAR}_{1}$ on dormancy release of Avena fatua caryopses include participation of non-enzymatic antioxidants and cell cycle activation in embryos. Planta 243:531-548. doi:10.1007/ s00425-015-2422-1

Cembrowska-Lech D, Kępczyński J (2017) Plant-derived smoke induced activity of amylases, DNA replication and $\beta$-tubulin accumulation before radicle protrusion of dormant Avena fatua L. caryopses. Acta Physiol Plant 39:39. doi:10.1007/s11738-0162329-x

Chang C, Wang B, Shi L, Li Y, Duo L, Zhang W (2010) Alleviation of salt stress-induced inhibition of seed germination in cucumber (Cucumis sativus L.) by ethylene and glutamate. J Plant Physiol 167:1152-1156. doi:10.1016/j.jplph.2010.03.018

Corbineau F, Xia Q, Bailly C, El-Maarouf-Bouteau H (2014) Ethylene, a key factor in the regulation of seed dormancy. Front Plant Sci 5:539. doi:10.3389/fpls.2014.00539

Costea M, Weaver SE, Tardif FJ (2004) The biology of Canadian weeds. 130. Amaranthus retroflexus L., A. powellii S. Watson and A. hybridus L. Can J Plant Sci 84:631-668. doi:10.4141/P02-183

D'Alessandro S, Posocco B, Costa A, Zahariou G, Schiavo FL, Carbonera D et al (2013) Limits in the use of cPTIO as nitric oxide scavenger and EPR probe in plant cells and seedlings. Front Plant Sci 4:340. doi:10.3389/fpls.2013.00340

de Castro RD, Bino RJ, Jing H-C, Kieft H, Hilhorst HWM (2001) Depth of dormancy in tomato (Lycopersicon esculentum Mill.) seeds is related to the progression of the cell cycle prior to the induction of dormancy. Seed Sci Res 11:45-54. doi:10.1079/ SSR200059

Egley GH (1989) Some effects of nitrate-treated soil upon the sensitivity of buried redroot pigweed (Amaranthus retroflexus L.) seeds to ethylene, temperature, light and carbon dioxide. Plant Cell Environ 12:581-588. doi:10.1111/j.1365-3040.1989. tb02131.x

Finkelstein R, Reeves W, Ariizumi T, Steber C (2008) Molecular aspects of seed dormancy. Annu Rev Plant Biol 59:387-415. doi:10.1146/annurev.arplant.59.032607.092740

Galbraith DW, Harkins KR, Maddox JM, Ayres NM, Sharma DP, Firoozabady E (1983) Rapid flow cytometric analysis of cell cycle in intact plant tissues. Science 220:1049-1051. doi:10. 1126/science. 220.4601 .1049

Gendreau E, Romaniello S, Barad S, Leymarie J, Benech-Arnold R, Corbineau F (2008) Regulation of cell cycle activity in the embryo of barley seeds during germination as related to grain hydration. J Exp Bot 59:203-212. doi:10.1093/jxb/erm296

Gendreau E, Cayla T, Corbineau F (2012) S phase of the cell cycle: a key phase for the regulation of thermodormancy in barley grain. J Exp Bot 63:5535-5543. doi:10.1093/jxb/ers204

Gniazdowska A, Dobrzyńska U, Babańczyk T, Bogatek R (2007) Breaking the apple embryo dormancy by nitric oxide involves the stimulation of ethylene production. Planta 225:1051-1057. doi:10.1007/s00425-006-0384-z

Gniazdowska A, Krasuska U, Bogatek R (2010) Dormancy removal in apple embryos by nitric oxide or cyanide involves modifications in ethylene biosynthetic pathways. Planta 232:1397-1407. doi:10.1007/s00425-010-1262-2

Hendricks SB, Taylorson RB (1974) Promotion of seed germination by nitrate, nitrite, hydroxylamine, and ammonium salts. Plant Physiol 54:304-309. doi:10.1104/pp.54.3.304
Holm L, Doll J, Holm E, Pancho J, Herberger J (eds) (1997) Amaranthus retroflexus L. and Amaranthus viridis L. In: World weeds: natural histories and distribution. Wiley, New York, pp 51-67

Karssen CM, Zagórski S, Kępczyński J, Groot SPC (1989) Key role for endogenous gibberellins in the control of seed germination. Ann Bot 63:71-80. doi:10.1093/oxfordjournals.aob.a087730

Kępczyński J (1986a) Ethylene-dependent action of gibberellin in seed germination of Amaranthus caudatus. Physiol Plant 67:584-587. doi:10.1111/j.1399-3054.1986.tb05059.x

Kępczyński J (1986b) Inhibition of Amaranthus caudatus seed germination by polyethylene glycol-6000 and abscisic acid and its reversal by ethephon or 1-aminocyclopropane-1-carboxylic acid. Physiol Plant 67:588-591. doi:10.1111/j.1399-3054.1986. tb05060.x

Kępczyński J, Karssen CM (1985) Requirement for the action of endogenous ethylene during germination of non-dormant seeds of Amaranthus caudatus. Physiol Plant 63:49-52. doi:10.1111/j. 1399-3054.1985.tb02816.x

Kępczyński J, Kępczyńska E (1997) Ethylene in seed dormancy and germination. Physiol Plant 101:720-726

Kępczyński J, Sznigir P (2013) Response of Amaranthus retroflexus L. seeds to gibberellic acid, ethylene and abscisic acid depending on duration of stratification and burial. Plant Growth Regul 70:15-26. doi:10.1007/s10725-012-9774-3

Kępczyński J, Sznigir P (2014) Participation of $\mathrm{GA}_{3}$, ethylene, NO and $\mathrm{HCN}$ in germination of Amaranthus retroflexus $\mathrm{L}$. seeds with various dormancy levels. Acta Physiol Plant 36:1463-1472. doi:10.1007/s11738-014-1524-x

Kępczyński J, Rudnicki RM, Khan AA (1977) Ethylene requirement for germination of partly after-ripened apple embryo. Physiol Plant 40:292-295. doi:10.1111/j.1399-3054.1977.tb04075.x

Kępczyński J, Corbineau F, Côme D (1996) Responsiveness of Amaranthus retroflexus seeds to ethephon, 1-aminocyclopropane 1-carboxylic acid and gibberellic acid in relation to temperature and dormancy. Plant Growth Regul 20:259-265. doi:10.1007/ BF00043316

Kępczyński J, Kępczyńska E, Bihun M (2003a) The involvement of ethylene in the release of primary dormancy in Amaranthus retroflexus seeds. Plant Growth Regul 39:57-62. doi:10.1023/A: 1021899805040

Kępczyński J, Bihun M, Kępczyńska E (2003b) The release of secondary dormancy by ethylene in Amaranthus caudatus L. seeds. Seed Sci Res 13:69-74. doi:10.1079/SSR2002125

Kępczyński J, Bihun M, Kępczyńska E (2006) Implication of ethylene in the release of secondary dormancy in Amaranthus caudatus L. seeds by gibberellins or cytokinin. Plant Growth Regul 48:119-126. doi:10.1007/s10725-005-5616-x

Krasuska U, Ciacka K, Andryka-Dudek P, Bogatek R, Gniazdowska A (2015) "Nitrosative door" in seed dormancy alleviation and germination. In: Igamberdiev AU, Gupta KJ (eds) Reactive oxygen and nitrogen species signaling and communication in plants. Springer, New York, pp 215-237

Lin Y, Yang L, Paul M, Zu Y, Tang Z (2013) Ethylene promotes germination of Arabidopsis seed under salinity by decreasing reactive oxygen species: evidence for the involvement of nitric oxide simulated by sodium nitroprusside. Plant Physiol Biochem 73:211-218. doi:10.1016/j.plaphy.2013.10.003

Liu X, Deng Z, Cheng H, He X, Song S (2011) Nitrite, sodium nitroprusside, potassium ferricyanide and hydrogen peroxide release dormancy of Amaranthus retroflexus seeds in a nitric oxide-dependent manner. Plant Growth Regul 64:155-161. doi:10.1007/s10725-010-9551-0

Masubelele NH, Dewitte W, Menges M, Maughan S, Collins C, Huntley R, Nieuwland J, Scofield S, Murray JAH (2005) D-type cyclins activate division in the root apex to promote seed 
germination in Arabidopsis. PNAS 102:15694-15699. doi:10. 1073/pnas.0507581102

Matilla AJ (2000) Ethylene in seed formation and germination. Seed Sci Res 10:111-126. doi:10.1017/S096025850000012X

Matilla AJ, Matilla-Vázquez MA (2008) Involvement of ethylene in seed physiology. Plant Sci 175:87-97. doi:10.1016/j.plantsci. 2008.01.014

Rodríguez MV, Barrero JM, Corbineau F, Gubler F, Benech-Arnold RL (2015) Dormancy in cereals (not too much, not so little): about the mechanisms behind this trait. Seed Sci Res 25:99-119. doi:10.1017/S0960258515000021

Rodríguez-Gacio MDC, Matilla-Vázquez MA, Matilla AJ (2009) Seed dormancy and ABA signaling. Plant Signal Behav 4:1035-1048. doi:10.4161/psb.4.11.9902

Schönbeck MW, Egley GH (1980) Redroot pigweed (Amaranthus retroflexus) seed germination responses to after ripening, temperature, ethylene, and some other environmental factors. Weed Sci 28:543-548. doi:10.1017/S0043174500061191 